\title{
DELIGNIFIKASI BONGGOL JAGUNG DENGAN METODE MICROWAVE ALKALI
}

\section{CORN CON DELIGNIFICATION WITH ALKALINE MICROWAVE METHOD}

\author{
Poppy Diana Sari ${ }^{1)}$, Wuwuh Asrining Puri' ${ }^{1)}$, Dinarta Hanum ${ }^{1)}$ \\ ${ }^{1)}$ Fakultas Teknik, Universitas Islam Majapahit, Mojokerto \\ Email: p.diana.sari@gmail.com
}

\begin{abstract}
ABSTRAK
Jagung adalah salah satu bahan makanan yang sangat potensial dijadikan bahan produksi berbagai makanan. Hasil panennya melimpah di Indonesia, begitu pula dengan limbah bonggol jagung yang dihasilkan. Bonggol jagung merupakan bahan lignoselulosa yang berpotensi tinggi untuk diolah menjadi berbagai produk. Gula sederhana yang dihasilkan dapat dimanfaatkan antara lain untuk bioethanol, asam karboksilat, sorbitol, xilitol dan asam amino. Penelitian ini bertujuan untuk mengetahui pengaruh perlakuan awal microwave alkali terhadap kandungan selulosa, lignin dan hemiselulosa pada bonggol jagung. Penelitian dilakukan dengan 2 perlakuan yaitu konsentrasi $\mathrm{NaOH}$ dengan 2 level perlakuan $1 \mathrm{~N}$ dan $2 \mathrm{~N}$, sedangkan perlakuan kedua adalah waktu perlakuan awal microwave alkali dengan 2 level perlakuan yaitu 30 menit dan 40 menit dengan pengaturan suhu rendah. Hasil penelitian diperoleh kadar selulosa tertinggi adalah sebesar 69,937\%, kadar lignin terendah adalah 9,006\% dan kadar hemiselulosa terendah adalah 13,797\%. Selulosa tertinggi serta lignin dan hemiselulosa terendah diperoleh pada perlakuan konsentrasi $\mathrm{NaOH} 2 \mathrm{~N}$ dan perlakuan awal selama 40 menit.
\end{abstract}

Kata kunci: Microwave alkali, bonggol jagung, selulosa, konsentrasi, waktu

\begin{abstract}
Corn is one of the foodstuff that potential to be used as an ingredient various production of food. It is abundant Indonesia, as well as its waste of corncob. Corncob is a high-potential lignocellulose material that can be processed into various products. The simple sugar produced can be used as bioethanol, carboxylic acid, sorbitol, xylitol, and amino acids. This study aims to determine the effect of alkali microwave perlakuan awal on the content of cellulose, lignin and hemicellulose in corncob. The study was carried out with 2 treatment, namely $\mathrm{NaOH}$ concentration with 2 levels of $1 \mathrm{~N}$ and $2 \mathrm{~N}$ treatments, while the second variable was pretreatment time with 2 levels of 30 minutes and 40 minutes with low temperature settings. The result were the highest cellulose content was $69.937 \%$, the lowest lignin level was $9.006 \%$ and the lowest hemicellulose level was $13.779 \%$. The highest cellulose and lowest lignin and hemicellulose were obtained in the treatment of $2 \mathrm{~N} \mathrm{NaOH}$ concentration and 40 minutes perlakuan awal.
\end{abstract}

Keywords: Alkaline microwave, corncob, cellulose, concentration, time. 


\section{PENDAHULUAN}

Jagung termasuk tanaman yang dapat tumbuh baik di daerah tropis seperti Indonesia. Sampai saat ini, jagung banyak digunakan sebagai bahan pangan karena mengandung banyak karbohidrat. Bagian jagung yang paling sering dimanfaatkan adalah biji atau bulirnya, sementara bonggol jagung dibuang begitu saja dan menjadi limbah. Dari data produksi Badan Pusat Statistik, diperkirakan limbah tongkol jagung dihasilkan di Indonesia sekitar 5,7 juta ton per tahun. Dengan melihat peluang limbah yang tak termanfaatkan tersebut, maka peluang pemanfaatan limbah tersebut untuk dijadikan energi semakin besar. Pemanfaatannya yang masih hanya sekedar untuk pakan ternak dan sisanya dibakar begitu saja menunjukkan kurang maksimalnya pemanfaatan bonggol jagung yang ada.

Menurut Lorenz dan Kulp (1991), bonggol jagung tersusun atas $41 \%$ selulosa, $36 \%$ hemiselulosa, 16\% lignin. Sedangkan Septiningrum dkk (2011) mengatakan bahwa bonggol jagung tersusun atas $26,81 \%$ selulosa, 30,91\% hemiselulosa, dan $15,52 \%$ lignin. Perbedaan hasil ini disebabkan oleh perbedaan bahan yang dipengaruhi oleh varietas, umur dan kondisi tanah tempat bahan tersebut ditanam (Jorgensen, et al., 2007). Dengan jumlah yang melimpah serta kandungan hemiselulosa dan selulosa yang tinggi, tongkol jagung mempunyai potensi yang besar untuk diolah menjadi produkproduk yang bernilai ekonomi tinggi.

Selulosa merupakan polimer rantai panjang D-glukosa dengan ikatan $\beta$ 1-4 glikosidik, sedangkan hemiselulosa lebih bersifat heterogen yang terdiri dari xilosa, galaktosa, manosa, arabinosa dan glukosa. Dengan hidrolisis tongkol jagung, maka akan dihasilkan gula sederhana seperti glukosa, xilosa, galaktosa, manosa dan arabinosa. Gula sederhana yang diperoleh merupakan bahan baku untuk berbagai produk olahan seperti asam karboksilat, sorbitol, xilitol, asam amino, bioethanol atau produk-produk lain yang lebih kompleks seperti protein sel tunggal.

Proses hidrolisis senyawa selulosa pada tongkol jagung memiliki beberapa cara yaitu secara kimia maupun enzimatis. Hambatan proses hidrolisis selulosa baik secara asam maupun enzimatis adalah karena strukturnya berbentuk kristalin dan lignin yang berfungsi sebagai pelindung selulosa (Judoamidjojo et al., 1989). 
Lignin adalah heteropolimer amorf yang terdiri dari tiga unit fenilpropan (pcoumaryl, coniferil dan sinapyl alkohol) yang terikat dengan ikatan yang berbeda. Fungsi utama lignin adalah memperkuat struktur tanaman dalam menahan serangan mikroba dan tekanan oksidasi (Hendriks dan Zeeman, 2009). Di dalam jaringan tanaman, lignin sulit didegradasi karena mempunyai struktur yang kompleks dan heterogen yang berikatan dengan selulosa dan hemiselulosa.

Berbagai sumber bahan lignoselulosa perlu dilakukan proses perlakuan awal lebih dahulu untuk mempermudah proses hidrolisis. Proses perlakuan awal akan membuat selulosa mudah ditembus oleh enzim selulolitik sehingga dapat mengurangi penggunaan enzim serta menekan biaya. Proses perlakuan awal dilakukan karena beberapa faktor seperti kandungan lignin, ukuran partikel serta kemampuan hidrolisis dari selulosa dan hemiselulosa (Hendriks dan Zeeman, 2009). Proses ini merupakan cara penting untuk proses konversi selulosa yang dapat dilakukan dengan berbagai metoda yaitu secara kimia, fisika maupun biologi. Selain itu juga untuk memisahkan selulosa dari ikatan lignin-hemiselulosa dan mengurangi kristal selulosa (Balan dkk,
2009). Menurut Mtui (2009), perlakuan awal terhadap limbah lignoselulosa dibedakan secara mekanik (dipotong, digerus, digiling), secara fisik (iradiasi dengan microwave, pirolisis, iradiasi gama), secara fisiko kimia, secara kimia, alkali, penambahan asam, asam organic serta proses organosolv.

Delignifikasi perlu dilakukan dikarenakan lignin merupakan penghambat utama pada proses hidrolisis selulosa. Lignin yang melindungi selulosa bersifat tahan terhadap hidrolisis karena adanya ikatan aril alkil dan ikatan eter (Perez et al., 2002). Lignin adalah salah satu komponen dalam kayu dan biomassa yang jumlah selulosanya pada kayu berkisar $25-30 \%$ dan pada bagas berkisar 20-30\%. Lignin merupakan jaringan polimer fenolik yang berfungsi merekatkan serat selulosa sehingga menjadi sangat kuat.

Ada beberapa metode delignifikasi yang umum diterapkan, yaitu secara mekanis, kimia dan semikimia. Namun, ketiga metode tersebut mempunyai beberapa kekurangan antara lain kebutuhan bahan kimia tinggi serta energi yang tinggi. Selain itu, limbah cair dari delignifikasi yang menggunakan bahan kimia tergolong limbah yang berbahaya karena bersifat toksik dan 
mencemari lingkungan (Martina, et al., 2002).

Foody et al., (1999) menyatakan bahwa perlakuan awal dapat dilakukan dengan mengkombinasikan perlakuan fisik dan kimia. Perlakuan fisik dapat berupa penggilingan, tekanan atau pengepresan, sedangkan perlakuan kimia dapat berupa penggunaan panas, pelarut atau asam. Perlakuan awal yang efisien harus dapat membebaskan struktur kristal selulosa dengan memperluas daerah amorf serta membebaskan dari lapisan lignin.

Terdapat berbagai metode perlakuan awal, baik secara konvensional maupun modern. Salah satu metode perlakuan awal modern adalah dengan menggunakan microwave. Proses pengubahan selulosa menjadi gula sederhana dapat dilakukan secara kimiawi maupun enzimatis. Ethaib et al. (2015) menyatakan bahwa perlakuan awal gabungan antara microwave dan kimia yang diaplikasikan pada berbagai jenis bahan baku yang berbeda menghasilkan pemulihan gula yang lebih tinggi dan larutan alkali menghilangkan lignin lebih banyak. Ethaib et al. (2015), menyatakan bahwa kombinasi perlakuan awal kimia dan microwave dari berbagai bahan baku menghasilkan selulosa yang lebih tinggi dan larutan alkali menghilangkan lignin. Menurut Dehani dkk. (2013), perlakuan awal lignoselulosa jerami padi menggunakan bantuan gelombang mikro berdaya 950 watt dan pelarut $\mathrm{NaOH} 0,5 \mathrm{M}$ pada waktu 40 menit dengan ukuran bubuk jerami 100 mesh dapat meningkatkan kadar selulosa jerami padi menjadi $42,32 \%$ yaitu dari $30,38 \%$ menjadi $72,70 \%$ dan menurunkan kadar lignin 4,27\% yaitu dari 7,93\% menjadi 3,66\%.

Gelombang mikro memiliki kemampuan dalam memecah struktur polimer dari lignoselulosa. Berdasarkan hasil penelitian Elwin dan Hendrawan (2014) perlakuan awal lignoselulosa menggunakan bahan eceng gondok menggunakan bantuan gelombang mikro berdaya 700 watt selama 30 menit dan pelarut $\mathrm{NaOH} 2 \mathrm{M}$ meningkatkan hasil selulosa dari $56 \%$ menjadi $68,27 \%$ dan menurunkan lignin dari $12,01 \%$ menjadi 11,50\%. Penelitian Sukowati dkk. (2014) melakukan perlakuan awal kulit pisang menggunakan $\mathrm{NaOH} 1 \mathrm{M}$ pada suhu $121{ }^{\circ} \mathrm{C}$ autoclave selama 15 menit menurunkan kandungan lignin dari 21,29\% menjadi $17,20 \%$ dan meningkatkan selulosa dari 
$14,56 \%$ menjadi $29,29 \%$. Kombinasi perlakuan awal microwave-perlakuan kimiawi terhadap perbedaan bahan berserat menghasilkan gula yang tinggi dan larutan alkali dapat mengurangi lignin, sehingga dirasa perlu dilakukan penelitian perlakuan awal terhadap tongkol jagung untuk mengubah komposisi lignoselulosa dan meningkatkan hasil hidrolisis tongkol jagung. Dengan dilakukan perlakuan awal microwave-alkali, dapat meningkatkan kadar selulosa serta menurunkan kadar lignin dan hemiselulosa yang terkandung dalamnya.

\section{METODE PENELITIAN}

Bahan-bahan yang digunakan dalam penelitian antara lain bagas tebu, $\mathrm{NaOH}$ dan aquades. Sedangkan alat-alat yang digunakan antara lain timbangan analitik, glassware, diskmill, microwave ayakan 100 mesh dan oven.

Penelitian dilakukan dengan 2 variabel perlakuan. Variabel pertama adalah konsentrasi $\mathrm{NaOH}$ dengan 2 level perlakuan yaitu $1 \mathrm{~N}$ dan $2 \mathrm{~N}$, sedangkan variabel kedua adalah waktu yang digunakan dalam perlakuan awal dengan dua level perlakuan yaitu 30 menit dan 40 menit. a. Persiapan bahan baku

Bonggol jagung yang diperoleh dibersihkan, dipotong kecil-kecil kemudian dijemur selama 2 hari di bawah sinar matahari hingga kering. Kemudian dihancurkan dengan menggunakan diskmill. Penyeragaman ukuran bubuk dilakukan dengan pengayakan dengan ayakan 100 mesh sehingga diperoleh bubuk bonggol jagung 100 mesh.

\section{b. Proses delignifikasi}

Bubuk bonggol jagung dimasukkan dalam Erlenmeyer, kemudian ditambahkan dengan larutan $\mathrm{NaOH}(1 \mathrm{~N}$ dan $2 \mathrm{~N}$ ) dengan perbandingan $1: 10$, kemudian memasukkan dalam microwave dan dibiarkan terpapar microwave sesuai dengan level perlakuan (30 dan 40 menit). Proses selanjutnya adalah proses netralisasi bonggol jagung yang telah diberi perlakuan awal. Proses netralisasi menggunakan aquades hingga $\mathrm{pH}$ bonggol jagung mencapai 7. Bonggol jagung yang telah netral dikeringkan dalam oven selama 12 jam, kemudian dilakukan pengamatan terhadap kadar selulosa, hemiselulosa dan lignin menggunakan metode Cheson (1981) dan dilakukan uji Scanning Electron Microscope (SEM). 


\section{HASIL DAN PEMBAHASAN}

Bonggol jagung yang digunakan dalam penelitian ini diperoleh dari daerah Mantup, Lamongan. Penelitian dilakukan di laboratorium Teknologi Hasil Pertanian, Universitas Islam Majapahit Mojokerto dan laboratorium Genetika dan Biomolekuler, Universitas Islam Negeri Maulana Malik Ibrahim Malang. Sedangkan uji Scanning Electron Microscope (SEM) dilakukan di laboratorium Sentral, Universitas Malang.

a. Kandungan Selulosa

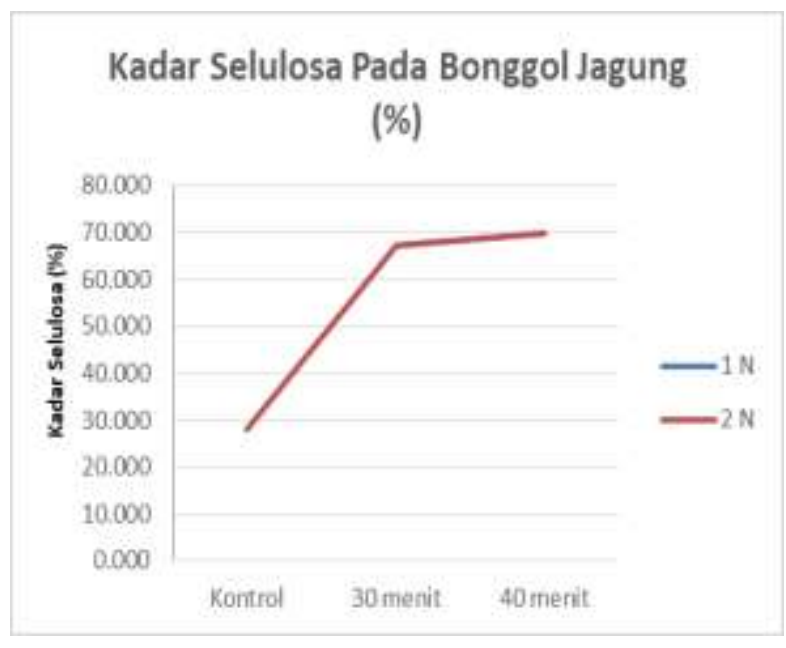

Gambar 1. Kadar Selulosa pada Bonggol Jagung

Dari diagram di atas dapat dilihat bahwa kandungan selulosa pada bonggol jagung setelah dilakukan perlakuan awal mengalami peningkatan baik dengan perlakuan konsentrasi $\mathrm{NaOH} 1 \mathrm{~N}$ ataupun 2 N. Semakin lama waktu perlakuan awal, semakin tinggi pula selulosa yang dihasilkan. Kadar selulosa tertinggi pada bonggol jagung maupun pada bagas tebu dalam penelitian ini terdapat pada perlakuan dengan konsentrasi $\mathrm{NaOH} 2 \mathrm{~N}$ dengan lama paparan microwave selama 40 menit. Bonggol jagung mengalami peningkatan selulosa tertinggi dari 28,082\% kadar selulosa awal menjadi $69,937 \%$ yaitu sebesar $149,0501 \%$.

b. Kandungan Hemiselulosa

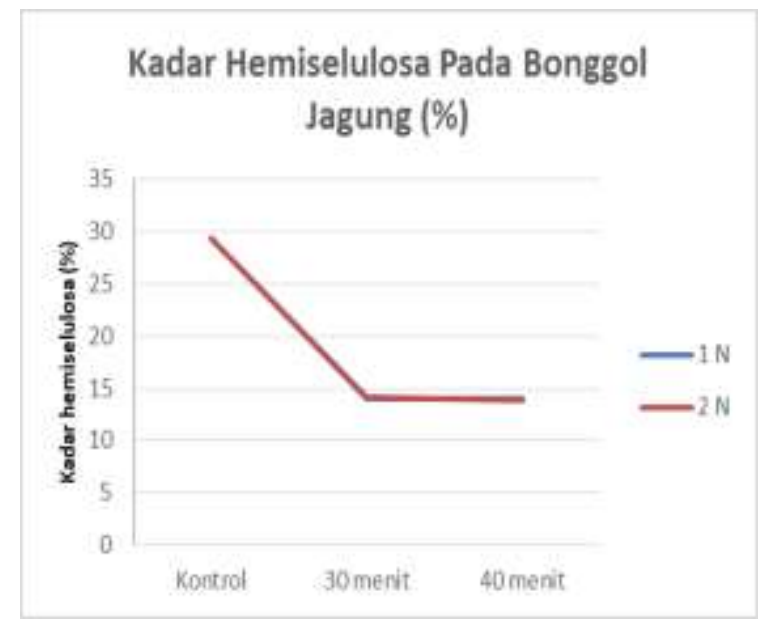

Gambar 2. Kadar Hemiselulosa pada Bonggol Jagung

Dari diagram di atas dapat dilihat tingkat penurunan yang signifikan baik dalam perlakuan dengan kosentrasi $\mathrm{NaOH} 1$ $\mathrm{N}$ maupun $2 \mathrm{~N}$. Hemiselulosa mengalami penurunan yang signifikan bila dibandingkan antara perlakuan kontrol atau 0 menit terhadap 30 menit perlakuan, namun 
tidak terjadi penurunan yang signifikan antara 30 menit dengan 40 menit. Penurunan hemiselulosa tertinggi terdapat pada perlakuan $\mathrm{NaOH}$ konsentrasi $2 \mathrm{~N}$ dengan lama paparan microwave 40 menit. Kadar hemiselulosa pada bonggol jagung mengalami penurunan tertinggi sebesar $53,13085 \%$, yaitu $29,437 \%$ pada perlakuan kontrol atau 0 menit perlakuan menjadi 13,797\% pada akhir perlakuan awal.

c. Kandungan Lignin

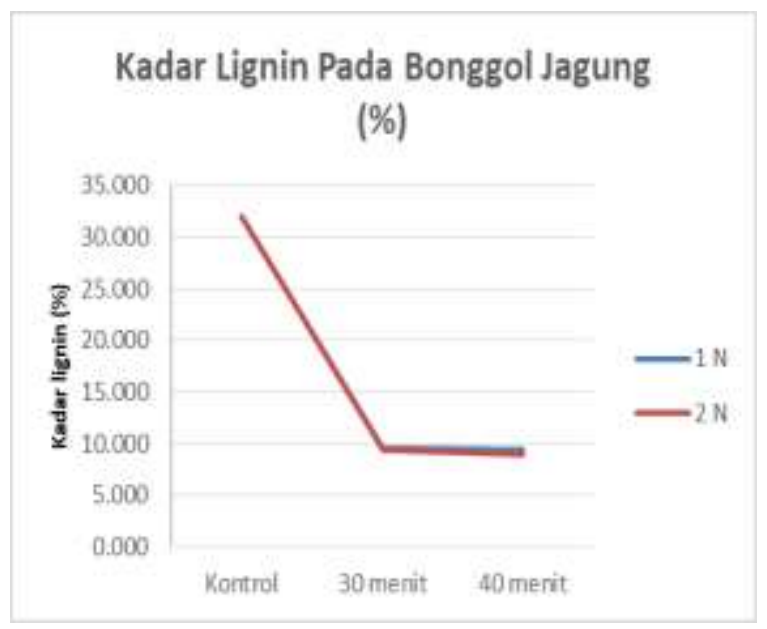

Gambar 3. Kadar Lignin pada Bonggol Jagung

Semakin lama paparan microwave terhadap bahan dalam larutan alkali, mengakibatkan lignin yang didegradasi lebih banyak jumlahnya. Hal ini berkaitan dengan efek panas yang ditimbulkan selama waktu paparan microwave. Semakin lama waktu paparan maka efek panas juga meningkat sehingga mampu mendegradasi ikatan dalam lignin lebih banyak sehingga kadar lignin semakin menurun seiring dengan semakin lama paparan microwave. Hal ini sesuai dengan pendapat Zhu et al. (2005) yang menyatakan bahwa radiasi microwave dapat meningkatkan reaksi degradasi lignin dalam larutan $\mathrm{NaOH}$. Dalam penelitian ini penurunan tertinggi kandungan lignin pada bonggol jagung adalah sebesar 71,8785\% dari $32,025 \%$ menjadi $9,006 \%$ pada perlakuan dengan konsentrasi $\mathrm{NaOH} 2 \mathrm{~N}$ dan 40 menit lama paparan microwave.

\section{d. Hasil Uji Scanning Electron Microscope (SEM)}

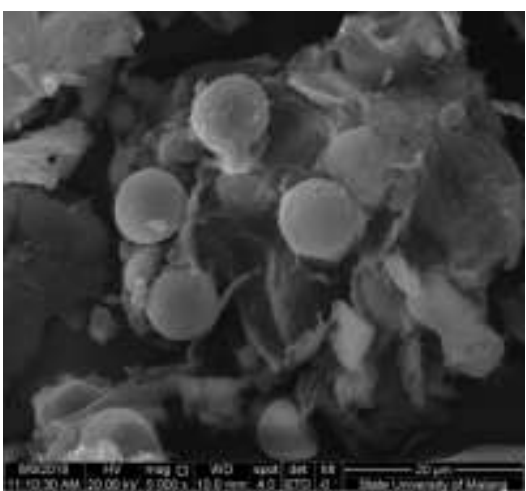

Gambar 4. Hasil uji Scanning Electron Microscope (SEM) dari Bonggol Jagung pada Perlakuan Kontrol dengan Pembesaran 2500 Kali 


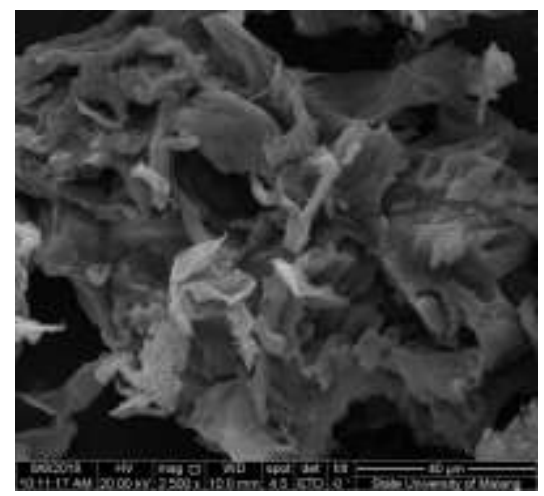

Gambar 5. Hasil uji Scanning Electron Microscope (SEM) dari Bonggol Jagung pada Perlakuan Kontrol Hasil Perlakuan Awal dengan $\mathrm{NaOH} 2 \mathrm{~N}$ dengan Lama Paparan 40 Menit dengan Pembesaran 2500 Kali

Dari gambar di atas dapat dilihat bahwa pada hasil uji Scanning Electron Microscope (SEM) bonggol jagung kontrol, terdapat hamparan luas yang merupakan lapisan luar dari bonggol jagung bubuk tanpa perlakuan awal. Sedangkan pada gambar hasil uji Scanning Electron Microscope (SEM) hasil perlakuan awal dengan $\mathrm{NaOH} 2 \mathrm{~N}$ dengan lama paparan 40 menit dapat dilihat bahwa terdapat banyak bagian yang hancur dan terdapat lubanglubang yang diakibatkan oleh adanya $\mathrm{NaOH}$ sebagai alkali dan panas serta gelombang radiasi dari microwave, sehingga memudahkan selulosa dan hemiselulosa keluar dari lapisan lignin.

\section{KESIMPULAN}

Dari penelitian yang telah dilakukan, dapat ditarik kesimpulan bahwa semakin tinggi konsentrasi $\mathrm{NaOH}$ dan semakin lama waktu paparan radiasi elektromagnetik dari microwave yang diberikan, semakin rendah kandungan lignin dan hemiselulosa, serta semakin tinggi kandungan selulosa yang diperoleh. Dari penelitian yang dilakukan, diperoleh kadar selulosa tertinggi adalah sebesar 69,937\%, kadar lignin terendah adalah 9,006\% dan kadar hemiselulosa terendah adalah $13,797 \%$. Selulosa tertinggi serta lignin dan hemiselulosa terendah diperoleh pada perlakuan konsentrasi $\mathrm{NaOH}$ $2 \mathrm{~N}$ dan perlakuan awal selama 40 menit.

\section{DAFTAR PUSTAKA}

Balan, V., B. Bals, S.P.S. Chundawat, D. Marshall, and B.E. Dale. 2009. Lignocellulose Biomass treatment Using AFEX. Method in Molecular Biology. 581: 61-77.

Dehani, F.R., B.D. Argo dan R. Yulianingsih. 2013. Pemanfaatan iradiasi gelombang mikro untuk memaksimalkan proses perlakuan awal degradasi lignin jerami padi (pada produksi bioetanol). Jurnal Bioproses Komoditas Tropis. 1(1): 1320.

Elwin, L.M. dan Y. Hendrawan . 2014. Analisis pengaruh waktu perlakuan 
awal dan konsentrasi $\mathrm{NaOH}$ terhadap kandungan selulosa, lignin dan hemiselulosa enceng gondok pada proses perlakuan awal pembuatan bioetanol. Jurnal Keteknikan Pertanian Tropis dan Biosistem. 2(2): 110-116.

Ethaib, S., R. Omar, S., M. M. Kamal \& R. A. Biak. 2015. Microwave-Assisted Perlakuan awal Of Lignocellulosic Biomass: A Review. Journal of Engineering Science and Technology. 97-109.

Foody, B., J. S. Tolan \& J. D. Bernstein. 1999. Perlakuan awal Process for Conversion of Cellulose to Fuel Ethanol. U.S. Pat. No. 6.090.595.

Hendriks, A.T.W.M., and G. Zeeman. 2009. Perlakuan awals to Enhance the Digestibility of Lignocellulose Biomass. Biores Technol. 8: 10-18.

Jorgensen, H., J. B. Kristensen and C. Felby. 2007. Enzymatic conversion of lignocellulose into fermentable sugars: challenges and opportunities Biofuels, Bioprod. Bioref. 1:119-134.

Judoamidjojo, R.M., E.G. Sa'id, dan L. Hartoto. 1989. Biokonversi. Bogor: Departemen Pendidikan dan Kebudayaan, Dirjen Dikti, Pusat Antar Universitas Bioteknologi Institut Pertanian Bogor.

Lorenz, K.J. and K. Kulp. 1991. Handbook of Cereal Science and Technology. Marcel Dekker, New York.

Martina A, N. Yuli dan M. Sutisna. 2002. Optimasi beberapa faktor fisik terhadap laju degradasi selulosa kayu albasia (Paraserianthes falcataria L.) Nielsen dan karboksimetilselulosa (CMC) serta enzimatik oleh jamur. J Nat Indonesia 4(2): 156-163. Miller GC. 19.

Mtui, Y.S. 2009. Recent Advances in Perlakuan awal of Lignocellulosic Wastes and Production of Value Added Products. African J. of Biotechnology Vol. 8(8): 1398-1415.

Perez, J., J.M. Dorado, T. Rubia, J. Martinez. 2002. Biodegradation and Biological treatments of Cellulose, Hemicellulose and Lignin: An Overview. Int. Microbiol. 5: 53- 63.

Septiningrum, K., Apriana dan Chandra. 2011. Produksi xilanase dari tongkol jagung dengan system bioproses menggunakan Bacillus circulans untuk pra-pemutihan pulp. Bandung: Balai besar pulp dan kertas, kementerian perindustrian Indonesia. V(1): 87-97.

Sukowati, A., Sutikno dan S. Rizal. 2014. Produksi bioetanol dari kulit pisang melalui hidrolisis asam sulfat. Jurnal Teknologi dan Industri Hasil Pertanian. 19(3): 274-288.

Zhu, S. D., Y.X. Wu, Z.N. Yu, J.T. Liao \& Y. Zhang. 2005. Perlakuan awal by microwave/alkali of rice straw and its enzymatic hydrolysis, Process Biochem. 40: 3082-3086. 